\title{
Constitutional Debates on Parliamentary Inviolability in Turkey
}

\author{
Ergun Özbudun*
}

Differences between parliamentary inviolability and parliamentary non-liability. Parliamentary inviolability in the Turkish constitution. Also for ministers. Scope and duration. Lifting of inviolability by the Grand National Assembly. Possibility of judicial review. Constitutional amendments to limit inviolability in the combat against corruption rejected.

The scope of parliamentary inviolability has become a matter of intense constitutional debate in Turkey in recent years. There has been a strong mood in the public opinion to limit, even to abolish it in corruption-related cases. This is seen as an important element in the overall fight against corruption. However, two constitutional amendment proposals aimed at limiting inviolability failed to receive sufficient parliamentary support. These failed attempts and the current debate are the subject of the last section of this contribution. Before that, the Turkish constitutional rules on inviolability will be discussed. Although they generally follow the more or less common European pattern, they also show some very interesting particularities. However, first some remarks on the differences between parliamentary inviolability and the related concept of parliamentary non-liability.

\section{PARLIAMENTARY INVIOLABILITY AND PARLIAMENTARY NON-LIABILITY}

Parliamentary inviolability should be distinguished from parliamentary non-liability. Both are immunities or privileges recognised to the members of Parliament in order to protect the public interest. Although these two institutions are generally treated together under the title of parliamentary immunities, they are different in terms of their legal nature and the interests they specifically protect. The aim of parliamentary non-liability is to protect the freedom of expression of members of Parliament in their parliamentary activities, thereby ensuring that

* Professor of Constitutional Law and Political Science, Bilkent University, Turkey. 
they can perform their parliamentary duties without the fear of punishment. Inviolability (freedom from arrest) is to protect the members of Parliament from politically motivated, arbitrary or unfounded criminal prosecution for acts not carried out in the performance of their parliamentary duties. This is to ensure that they can attend to their parliamentary duties without undue interruptions.

Parallel to this difference, parliamentary non-liability generally affords the members of Parliament an absolute and permanent protection, while inviolability protects them only in a relative sense and for a certain period (for the duration of the legislature or the duration of the sessions). Thus, the title of Article 83 of the Turkish Constitution ('parliamentary inviolability'), which regulates both nonliability and inviolability, is misleading. It should have been 'parliamentary immunities', a generic term which covers both privileges.

While parliamentary non-liability is recognised in all European countries in very similar terms, with regard to inviolability, national regulations display much greater variations. For instance, in the Netherlands, members of Parliament have no parliamentary inviolability since 1884 . In Canada, Ireland, Malta, and the United Kingdom, inviolability protects members of Parliament only from detention or arrest in civil proceedings. On the other hand, a great majority of European countries also recognise inviolability to a greater or lesser extent in the area of criminal proceedings. ${ }^{1}$

\section{Article 83 of the Turkish Constitution and its exceptions}

The Turkish Constitution of 1982 explicitly recognises inviolability, following the tradition of the 1924 and the 1961 Constitutions. According to Article 83 paragraph 2 of the Constitution:

A deputy who is alleged to have committed an offence before or after election, cannot be detained, interrogated, arrested or tried unless the Assembly decides otherwise. This provision shall not apply in cases where a member is caught in the act of committing an offence punishable by a heavy penalty and in cases subject to Article 14 of the Constitution if an investigation has been initiated before the election. However, in such situations the competent authority shall notify the Grand National Assembly of Turkey immediately and directly. ${ }^{2}$

Another consequence of parliamentary inviolability in Turkey is the suspension of the execution of a criminal sentence. According to paragraph 3 of Article 83, 'the

${ }^{1}$ In this study, the information concerning the regulations in European countries has been obtained from a report of the Venice Commission of the Council of Europe, Report on the Regime of Parliamentary Immunity, CDL-INF (96) 7 (Strasbourg, 4 June 1996).

${ }^{2}$ Art. 14 shall be discussed below. 
execution of a criminal sentence imposed on a member of the Grand National Assembly of Turkey either before or after his election is suspended until the end of his membership; the statute of limitations does not operate during the term of his membership'. It is needless to say that the sentence referred to in Article 83 can only be a relatively light sentence which does not disqualify him from eligibility and which accordingly does not entail the loss of membership in accordance with Article $84 .^{3}$

The prime minister and the other ministers also enjoy parliamentary inviolability. The prime minister has to be a parliamentarian; according to Article 109, paragraph 2, of the Constitution he is appointed by the President of the Republic from among the members of the Turkish Grand National Assembly. Ministers do not have to be parliamentarians, but if they are not, they nevertheless enjoy inviolability (Article 112, paragraph 5).

Article 83 provides for two situations in which a deputy can be detained, interrogated, arrested, or tried without a preliminary decision of the Assembly. The first concerns members of Parliament caught in flagrante delicto. This exception is encountered in all European constitutions which recognise inviolability in criminal matters. In addition, in some European countries, certain heavy crimes are excluded from the scope of inviolability even if the deputies are not caught in the act. For example in Sweden crimes involving more than two years of imprisonment do not benefit from inviolability. In some other European countries a crime, in addition, should involve a constitutionally prescribed minimum penalty in order to be excluded from the scope of inviolability (Portugal, Croatia, Finland, and Slovenia). Similarly, in Turkey for this exception to be applicable the members of Parliament should not only have been caught in the act (as defined by Article 127 of the Criminal Procedure Code), but also the act involved should be punishable with a 'heavy penalty'. According to Article 421 of the Criminal Procedure Code, crimes involving death penalty, 'heavy imprisonment' (a strict detention regime), ${ }^{4}$ or imprisonment for more than ten years are considered acts punishable with a heavy penalty. ${ }^{5}$ This exception is reasonable, since in this case there is a strong presumption about the seriousness of the accusation.

\footnotetext{
${ }^{3}$ The relevant para. 2 of Art. 84 reads: 'The loss of membership through a final judicial sentence or loss of legal capacity take effect after the final court decision on the matter has been communicated to the plenary of the Grand National Assembly of Turkey'. Relevant is also para. 5 of Art. 84, which states that 'the membership of a deputy whose statements and acts are cited in the final verdict of the Constitutional Court in a case leading to the permanent prohibition of a political party, as having caused the prohibition of his party, terminates on the date when this verdict is published in the Official Gazette'.

${ }^{4}$ In the new Criminal Code which entered into force on 1 April 2005 the distinction between imprisonment and heavy imprisonment has disappeared.

${ }^{5}$ Kemal Gözler, Türk Anayasa Hukuku [Turkish Constitutional Law] (Bursa, Ekin Kitabevi Yayınları 2000), p. 324-325.
} 
While there are thus strong grounds for excluding the cases of flagrante delicto from the inviolability rule, the same cannot be said for the second exception provided for by Article 83, i.e., the cases subject to Article 14 of the Constitution. Article 14 regulates the abuse of fundamental rights and liberties. Especially in its original version Article 14 referred to concepts and principles which are exceedingly broad and ambiguous. This made it not easy objectively to determine to which particular crimes they corresponded. In addition, the seriousness of the crime that is alleged to have been committed does not always reflect the fairness and non-arbitrariness of the accusation. ${ }^{6}$ Article 14 originally read as follows:

None of the rights and freedoms embodied in the Constitution can be exercised with the aim of violating the indivisible integrity of the State with its territory and nation, of endangering the existence of the Turkish State and Republic, of destroying fundamental rights and freedoms, of placing the government of the State under the control of an individual or a group of people, or establishing the hegemony of one social class over others, or creating discrimination on the basis of language, race, religion or sect, or of establishing by any other means a system of government based on those concepts and ideas.

The constitutional amendment of 2001 made the provision simpler and more straightforward, eliminating many of the highly broad and ambiguous criteria. Thus, the new text states that

None of the provisions of this Constitution can be interpreted in a manner that would grant the right of destroying the rights and freedoms embodied in the Constitution. None of the rights and freedoms embodied in the Constitution can be exercised for activities undertaken with the aim of violating the indivisible integrity of the State with its territory and nation, and endangering the existence of the democratic and secular Republic based on human rights. No provision of the Constitution can be interpreted in a manner that would enable the State or the individuals to engage in activities with the aim of destroying the fundamental rights and freedoms embodied in the Constitution or of restricting them more extensively than is stated in the Constitution.

It should be pointed out, however, that since the adoption of the 1982 Constitution, governmental authorities have never availed themselves of the opportunity to use the reference to Article 14 in inviolability cases. In the few cases where inviolability was lifted, this was done through due constitutional procedures as will be spelled out below.

${ }^{6}$ Ibid., p. 326; cf. Ergun Özbudun, Türk Anayasa Hukuku [Turkish Constitutional Law] (Ankara, Yetkin Yayınları 2002) p. 280; Zafer Gören, Anayasa Hukukuna Girişs [Introduction to Constitutional Law](İzmir, Fakülteler Kitabevi 1997), p. 216. 


\section{SCOPE AND DURATION}

While it is a matter of debate in Turkish constitutional law whether parliamentary non-liability covers also civil proceedings, ${ }^{7}$ there is no doubt that such proceedings are not included in the scope of inviolability, since such proceedings do not interfere with the performance of a deputy's legislative duties. Furthermore, under Article 38 of the Constitution as amended in 2001, there can be no detentions or arrests in civil law suits. The amended Article states that 'no one shall be deprived of his liberty merely on the ground of inability to fulfil a contractual obligation'. Here contractual obligation should be interpreted as covering all civil relations.

When it comes to criminal proceedings, Article 83 of the Constitution protects deputies against detention, interrogation, arrest and trial. According to the dominant view in Turkish criminal procedure law doctrine, this rule does not preclude the possibility of taking other procedural steps such as initiating an investigation, collecting evidence and making a house search. ${ }^{8}$ As in France, Portugal, Greece and Japan, inviolability does not exclude the initiation of an investigation. In contrast, in for instance Italy initiating an investigation and the searching of premises of members of Parliament concerned are excluded.

In some countries, the protection is afforded only in the duration of parliamentary sessions (Latvia, Liechtenstein, Lithuania, Luxembourg, Norway, Sweden, Switzerland). In Canada, the duration of inviolability covers parliamentary sessions, as well as 40 days before and 40 days after the sessions. However, in a majority of European countries that recognise inviolability, this immunity protects the member of Parliament for his/her entire mandate. This is also the case in Turkey.

\section{LIFTING OF PARLIAMENTARY INVIOLABILITY AND JUDICIAL REVIEW}

In all European countries which recognise parliamentary inviolability, such immunity can be lifted by a resolution of the parliamentary assembly to which the member belongs. In Turkey, the procedure to be followed is regulated by the Standing Orders of the Grand National Assembly, according to which requests for the lifting of inviolability is forwarded by the Speaker of the Assembly to a mixed committee composed of the members of the Justice and Constitutional Commit-

${ }^{7}$ Gözler, supra n. 5, at p. 322; Özbudun, supra n. 6, at p. 278; Akman Akyürek, Parlamenterlerin Yasama Faaliyetlerinden Dolay Hukuki ve Cezai Sorumlulukları (Doktrin, Uygulama, Yargitay Íçtihatlarr) [Civil and Criminal Responsibility of Parliamentarians on Account of their Legislative Activities: Doctrine, Practice, Supreme Court Decisions] (Ankara, Başbakanlik Basımevi 1991).

${ }^{8}$ Gözler, supra n. 5, at p. 324; Nurullah Kunter, Ceza Muhakemesi Hukuku [Criminal Procedure Law] (İstanbul, Kazancı Yayınları 1986) p. 89; Sulhi Dönmezer ve Sahir Erman, Nazari ve Tatbiki Ceza Hukuku [Theoretical and Practical Criminal Law] (İstanbul, Filiz Kitabevi 1985) p. 256. In practice, however, inviolability also precludes the initiating of investigations. 
tee. The Chairperson of the Mixed Committee composes a five-member preparatory committee by drawing of lots. The Mixed Committee, after having considered the report of the preparatory committee, decides either to lift inviolability or to defer the proceedings until the end of the mandate. If the Mixed Committee's decision is in favour of deferment, its report is read in the plenary session of the Assembly. If no deputy objects to it in ten days in writing, it becomes final. If the Mixed Committee recommends the lifting of inviolability or if a deputy objects to deferment, then the matter is debated in the plenary session. The deputy concerned may defend himself/herself in the preparatory committee, the Mixed Committee, and the plenary session.

The deputy's request for the lifting of his/her own inviolability does not provide sufficient grounds for the lifting of inviolability by the Assembly, since, as in France and Belgium, in Turkey this immunity has a public policy status and is adopted not for the personal benefit of the deputy but in order to protect public interest.

Under paragraph 4 of Article 83, criminal proceedings against a re-elected deputy can be initiated only if the Assembly decides to lift his immunity again. In other words, the parliamentary resolution lifting the inviolability of a deputy becomes invalid with his/her re-election.

In all European countries the parliamentary resolution to lift inviolability is considered as an essentially political decision entirely within the discretion of the legislative assembly to which the member belongs. However, it can be argued that if the accusation is manifestly arbitrary or politically motivated (fumus persecutionis) the assembly should refrain from doing so. Here, in comparative perspective a particularity of the Turkish regime comes to the fore. The Turkish Constitution, in order to protect the assembly's decision from political motivations as far as possible, prohibits parliamentary group debates and decisions in matters involving the lifting of inviolability (Article 83, paragraph 5).

Also, Turkey is the only European country which subjects such parliamentary resolutions to judicial review. The possibility of review existed already under the Constitution of 1961 and is nowadays embodied in Article 85 of the Constitution, according to which:

'If the Grand National Assembly of Turkey decides to lift the parliamentary inviolability of a member (...), the member concerned or any member (...) may, within a week of the decision, appeal to the Constitutional Court for the decision to be annulled on the grounds that it is in conflict with the Constitution, the law, or the Standing Orders. The Constitutional Court makes a final verdict on the appeal within fifteen days'. 
It should be noted that the Constitutional Court's decision does not involve the ascertainment of the facts of the alleged crime, but only of the seriousness and fairness of the accusation. However, to arrive at a judgment on this issue, the Constitutional Court should obviously carry out a preliminary investigation concerning the reliability of the evidence. Although there have been a few appeals under the 1982 Constitution, none of them was found admissible by the Court. Under the 1961 Constitution, however, the Court annulled a parliamentary resolution lifting the inviolability of a member of Parliament. ${ }^{9}$ In this decision, the Constitutional Court decided that the tapes of conversations and the reports of secret agents, unless supported by other evidence, do not constitute sufficiently reliable evidence to describe an accusation as 'serious' as stipulated by Standing Orders of the Senate of the Republic (one of the two chambers of parliament under the 1961 Constitution).

While Turkey is the only European country which subjects such parliamentary resolutions to judicial review, in some countries (France, Germany, Austria) the legislative assembly may request the suspension of proceedings against, or of the detention of, one of its members until the end of his mandate, if it considers that the flagrante delicto exception has been used unreasonably. This is not the case in Turkey, but the Turkish system can be defended as one which provides maximum protection for deputies against the unfounded and politically motivated resolutions of parliamentary majorities.

\section{DEBATES ON THE NECESSITY OF PARLIAMENTARY INVIOLABILITY AND ATTEMPTS TO AMEND THE CONSTITUTION}

In recent years, there has been a vivid debate in Turkey on the need to limit parliamentary inviolability. There have even been proposals to abolish it altogether, while retaining parliamentary non-liability. Behind these proposals lie the widespread incidence of corruption and the suspicion that some deputies are involved in it.

In 1997 a first attempt was made to amend the Constitution. An amendment proposal signed by 292 deputies, including the leaders of the Motherland, the True Path, and the Republican People's parties, was submitted to the Assembly on 23 January 1997. The proposal aimed at the abolition of inviolability for the socalled dishonourable offences, such as embezzlement, corruption, bribery, theft, fraud, forgery, breach of trust, fraudulent bankruptcy, smuggling, and conspiracy in official procurements and sales. However, even in such cases, the detention or

${ }^{9}$ E. 1971/141, K. 1971/67, decision date 17 Aug. 1971 and 19 Aug. 1971, AMKD [Reports of the Decisions of the Constitutional Court] No. 11, p. 52-96 (this concerns one decision which was given two dates). 
arrest of a deputy still required a decision of the Assembly. In other words, the proposal aimed at abolishing inviolability only with regard to investigation and trial. It is to be pointed out here that such offences are also offences which bar the eligibility to parliament and disqualify the deputy from membership if he is sentenced while serving in the Assembly. The second reading of this proposal was postponed five times, and finally it was rejected on 17 March 1999.

A second, and more modest, attempt to limit inviolability was made in 2001. The amendment proposal provided for the abolition of paragraph 4 of Article 83, which stipulated that in case of re-election, criminal proceedings against a deputy can continue only if the Assembly decides to lift his immunity again. Furthermore, the proposal provided for the addition of three new paragraphs to Article 83 , according to which

- The proceedings on inviolability must be completed within three months commencing from the date of its reception by the Assembly.

- Voting on the lifting of inviolability is cast by a secret ballot of the Plenary Session.

- Criminal suits concerning deputies shall be tried by the Court of Cassation. The principles according to which the preliminary investigation is carried out, the initiation of a public suit, the appeal against the sentence, and other principles of trial shall be regulated by law.

This proposal, while containing certain positive elements to facilitate and accelerate the process of lifting inviolability, was falling behind the expectations of public opinion, which was in favour of a more severe limitation of inviolability. Nevertheless, even this rather modest amendment proposal failed to receive the required number of votes and was rejected. ${ }^{10}$

Limiting parliamentary inviolability was one of the issues debated during the 2002 election campaign. Both parties now represented in parliament, the AKP (Justice and Development Party) and the CHP (Republican People's Party) went on the record favouring such limitations. However, no steps have been taken in this direction since the elections. The CHP seems to be in favour of the total abolition of inviolability, while retaining non-liability. The AKP, on the other hand, seems to be willing to consider the issue only as part of a broader constitutional amendment package. The AKP spokesmen insist that, together with parliamentary inviolability, other immunities protecting civil servants from direct criminal investigation should also be reconsidered. Perhaps, a formula along the

\footnotetext{
${ }^{10}$ For these two unsuccessful attempts, see Ömer Faruk Gençkaya, 'Politics of Constitutional Amendment in Turkey, 1987-2002', in Constitutions of the Countries of the World: Turkey (Dobbs Ferry, Oceana Publications 2003) p. XVIII-X/I, X/V.
} 
lines of the failed 1997 constitutional amendment attempt may provide a reasonable basis for compromise in this matter.

\section{To CONCLUde}

The failure of the two attempts to amend the Constitution in order to limit parliamentary inviolability reflects the sensitivity of a large number of deputies on this issue. Turkish parliamentarians seem to be extremely jealous of their privileges. Hence, it appears unlikely that a new attempt in this direction will succeed. Moreover, the more radical proposals aiming at the total abolition of inviolability seem highly unrealistic. A large majority of European countries have recognised parliamentary inviolability in criminal proceedings in one way or another. It may be argued that inviolability has lost some of its original importance, given the fact that in all Western democracies the judiciary has become essentially independent of the executive branch. Still, the possibility that the executive authorities may be able to influence judicial authorities in more subtle ways or that the courts may be open to other political influences cannot be altogether eliminated. Thus, it may be concluded that parliamentary inviolability still continues to be a fairly important guarantee for deputies. 